\title{
SOCJOLOGIA POLSKA I CZESKA: WZAJEMNE STOSUNKI, ICH CHARAKTER I KONTEKSTY ${ }^{1}$
}

Jarosław Kilias

Uniwersytet Warszawski

Tematem artykułu nie jest, ściśle rzecz biorąc, wędrówka pojęć, a wzajemne kontakty i współpraca uczonych z Polski i Czech (w latach 1918-1939 i 1945-1992: Czechosłowacji). Obecnie ich skala i znaczenie sa ograniczone, jednak w przeszłości istotnie wpływały one na rozwój nauki, bardziej zresztą w Czechach niż w Polsce. Jeśli chodzi o wymianę pojęć i idei, to relacje polsko-czeskie stanowią ciekawy przypadek częstokroć intensywnej, choć nierzadko jednostronnej wzajemnej relacji, która jednak nie skutkowała szczególnie wielkim transferem powstających tam oryginalnych koncepcji. W tekście zamierzam wobec tego przedstawić syntetyczny opis stosunków polsko-czechosłowackich oraz spróbować wskazać czynniki określające ich charakter, zarówno przynależne do szerszego kontekstu społecznego i kulturowego, jak i stanowiące efekt oddziaływania lokalnych, formalnych i nieformalnych instytucji naukowych.

\section{/// Socjologia w Polsce i w Czechach: równoległość historii i odmienność kontekstów}

Historię dyscypliny w obu krajach cechuje wiele podobieństw - czasem istotnych, czasem powierzchownych i przesłaniających nie mniej znaczące różnice ${ }^{2}$ I na ziemiach polskich, i w Czechach zalą̇zi socjologii pojawiły się w drugiej połowie XIX wieku, nowa zaś nauka stano-

\footnotetext{
1 Artykuł powstał w ramach projektu Socjologia polska lat 60. XX wieku w kontekście socjologii światowej, sfinansowanego ze środków NCN przyznanych na podstawie decyzji nr 2013/09/B/HS6/00302.

2 Opisuję je głównie w oparciu o prace Jerzego Szackiego (1995), Niny Kraśko (1996, 2010) i Zdeňka Nešpora (2011, 2014). W dalszej części tekstu odsyłacze do nich zostały pominięte, chyba że ich obecność była absolutnie konieczna.
} 
wiła synonim postępowych idei pochodzących z Zachodu, uchodzących za odmienne czy wręcz obce rodzimej tradycji. Po I wojnie światowej socjologia uzyskała w obu krajach status dyscypliny akademickiej, przy czym u południowych sąsiadów instytucjonalizacja był szybsza i głębsza. Na wszystkich czechosłowackich uniwersytetach powstały katedry socjologii; wykształcono na nich ponad stu socjologów, więcej niż w Polsce (Nešpor 2014: 215-225, Sułek 2013). W Czechosłowacji socjologia cieszyła się dużym zainteresowaniem, uchodząc za element demokratycznego światopoglądu nowej Republiki. W pracach Masarykowskiego Towarzystwa Socjologicznego, jednego z dwóch czechosłowackich socjologicznych towarzystw naukowych, dużą rolę odgrywały osoby spoza kręgu profesjonalnych socjologów, a jego działalność miała w dużym stopniu charakter popularyzatorski. Inaczej niż w Polsce, w okresie II wojny światowej w Protektoracie Czech i Moraw działała czeska administracja wszystkich szczebli; choć zamknięto uniwersytety, funkcjonowała część instytucji kulturalnych oraz naukowych. Do 1940 roku wydawano „Sociologicką Revue”, jedno z dwóch pism socjologicznych, do końca zaś wojny działało Czeskie (dawniej Masarykowskie) Towarzystwo Socjologiczne i prowadzono - w ograniczonym zakresie - badania. Warto przy okazji dodać, że w powstałym w 1939 roku państwie słowackim socjologia uzyskała personalną i intelektualną niezależność od Czechów. Kadry przedwojennej socjologii czechosłowackiej, jak ja nazywano, wywodziły się zasadniczo z Czech, a dla najważniejszej postaci nauki słowackiej, Antona Štefánka, nauka długo była dodatkiem do kariery politycznej (Wincławski 1991: 117-148)3. Dystynktywną tożsamość nauka słowacka zachowała także po wojnie, podczas gdy charakter socjologii czechosłowackiej (termin ten pozostawał w powszechnym użyciu do upadku komunizmu) uprawianej przez uczonych czeskich pozostawał nie do końca zdefiniowany.

Po wojnie tak w Polsce, jak i w Czechosłowacji nauka odrodziła się w oparciu o ocalałe kadry, jednak u progu lat 50. XX wieku nastapiła jej likwidacja. W obu krajach proces ten wyglądał inaczej. W Polsce socjologowie bywali odsuwani od nauczania, na ogół jednak pozostawali w instytucjach akademickich, nierzadko na eksponowanych stanowiskach i w tej czy innej formie trwając przy swych zainteresowaniach naukowych. W powojennej Czechosłowacji wielką rolę wciąż odgrywali

\footnotetext{
Oficjalnie deklarowano istnienie jednego narodu i dwóch gałęzi jednego języka czechosłowackiego; ich bliskość powodowała, że wydane w Czechosłowacji prace były dostępne zarówno dla czeskich, jak i słowackich czytelników.
} 
uczeni starszej generacji, których bez wyjątku odesłano na emerytury. Młodszych usunięto, względnie musieli się przekwalifikować, a dyscyplina zniknęła z instytucji akademickich. Gdy zaczęła się odwilż, socjologia w Polsce natychmiast pojawiła się na nowo, przy czym udział w jej odrodzeniu mieli zarówno uczeni legitymujący się przedwojenną edukacją i socjologiczną praktyką naukową, jak i młodsi, czasem mający za sobą studia socjologiczne, często będący absolwentami komunistycznych instytucji kształcących kadry naukowe. W Czechosłowacji, gdzie polityczna odwilż następowała opornie, proces ten na dobrą sprawę zaczął się dopiero w latach 60 . i był wolniejszy, a twórcami nowej socjologii byli młodzi partyjni uczeni, niezainteresowani starszą socjologia (Voř́šsek 2012: 145-191).

Warto zauważyć, że przerwanie ciagłości dyscypliny w latach 50. przykrywa nie mniej zasadniczą nieciągłość, związaną z pojawieniem się i uzyskaniem hegemonii przez nowy, pochodzący ze Stanów Zjednoczonych styl uprawiania dyscypliny, oparty na dominacji badań sondażowych, psychologii społecznej jako narzędziu ich interpretacji oraz pozytywistycznej metodologii jako metateorii, w zakresie teorii zaś oznaczający panowanie parsonsowskiego funkcjonalizmu (Kilias 2012: 37-40). W obu krajach lata 60. XX wieku uchodzą za okres świetności lokalnych socjologii. W Polsce nauka ta miała pluralistyczny charakter jako dyscyplina uprawiana zarówno przez młodych marksistów i niemarksistów, jak i uczonych starszego pokolenia. Czechosłowacka socjologia stanowiła zasadniczo dzieło uczonych uformowanych przez doświadczenie stalinizmu, rozczarowanych nim i związanych z reformatorskim nurtem partii komunistycznej, przy czym ich diagnozy miały stanowić punkt wyjścia dla proponowanych reform (Vořŕšek 2012: 218, 396-400). W obu krajach na rozwoju dyscypliny znamię odcisnęły wydarzenia roku 1968. W Polsce oznaczał on wygnanie Marii Hirszowicz oraz Zygmunta Baumana, bodaj największej gwiazdy nowej socjologii. Na emigrację zdecydował się także Aleksander Matejko. Nastapiły zmiany organizacyjne i zacieśnienie administracyjnego nadzoru nad nauką; zmniejszył się też zakres swobody badań społecznych i publikowania ich rezultatów.

Choć rok 1968 nie stanowił zasadniczego przełomu w zakresie warunków uprawiania nauki, dzieje socjologii polskiej w latach 70. XX wieku zdają się świadczyć o stagnacji. Inne było jej usytuowanie w międzynarodowym życiu naukowym. W okresie tym socjologia zdążyła się już zadomowić w większości krajów europejskich, wliczając socjalistyczne, a nauka polska nic stanowiła już wśród nich unikatu. Rozrost dyscypli- 
ny, postępująca specjalizacja oraz zróżnicowanie teorii i metod badawczych przynosiły fragmentaryzację, utrudniającą uczonym zza ,żelaznej kurtyny" zdobywanie bardziej znaczącej pozycji w zachodnim obiegu naukowym i śledzenie postępów wiedzy. Po roku 1980 jeszcze bardziej widoczne stały się społeczne i polityczne niedomagania ustroju, a dzięki rozszerzeniu zakresu swobody intelektualnej zwiększyła się praktyczna możliwość ich analizowania. Last but not least, okres ten przyniósł też wzrost zainteresowania Zachodu, choć głównie ze strony badaczy polityki i specjalistów od Europy Środkowo-Wschodniej. W demokratycznej Polsce socjologia okazała się nieźle rozwiniętą nauką, cieszącą się niespotykana gdzie indziej estymą oraz przeżywającą intensywny rozwój instytucjonalny i intelektualny, choć nie mogła się pochwalić przełomowymi odkryciami ani nowatorskimi teoriami. Jak się wydaje, można tu mówić o rozwoju zależnym, polegającym na przejmowaniu płynących z Zachodu idei czy mód teoretycznych oraz dostarczaniu przetworzonych danych zagranicznym partnerom, dysponującym większym prestiżem, kontrolą nad najważniejszymi wydawnictwami naukowymi, a wreszcie większymi środkami finansowymi. Dowodzi tego choćby natura kontaktów zagranicznych kadry naukowej, długo odbywających się głównie dzięki środkom zachodnich instytucji finansujących naukę.

Losy czechosłowackiej socjologii ułożyły się mniej szczęśliwie. Interwencja krajów Układu Warszawskiego oznaczała kres programu reform i odejście w polityczny niebyt jego nosicieli. Proces ten, zwany w oficjalnej retoryce „normalizacja”, przebiegał stopniowo i przez pewien czas można było mieć nadzieję na zachowanie części zdobyczy Praskiej Wiosny. Tak się jednak nie stało, a triumf neostalinistów znaczyły kolejne czystki. Przy okazji „dostało się” intelektualnemu zapleczu reformatorów - socjologom i socjologii. Od pracy naukowej odsuwano nie tylko osoby zaangażowane $\mathrm{w}$ ich działalność, ale i nie dość gorliwych krytyków domniemanych błędów, a wreszcie tych wszystkich, którzy jakoś narazili się nowej ekipie. W praktyce oznaczało to pozbycie się większości wartościowej kadry naukowej, przy czym jedynie część „znormalizowanych” uczonych mogła uprawiać jakakkolwiek formę pracy badawczej czy w ogóle intelektualnej. W latach 70. instytucje akademickie w najlepszym razie odtwarzały zredukowane zasoby kadrowe; w Pradze, najsilniej dotkniętej czystkami, na pewien czas wstrzymano nawet nabór na studia (Petrusek 2004, Pecka 2011). Niemal ustały kontakty z nauką zachodnią. Z czasem sytuacja ustabilizowała się, zaczęto na nowo kształcić kadry, w latach 80. zaś można mówić o ożywieniu 
życia naukowego, nadal jednak spętanego ograniczeniami politycznymi i ideologicznymi silniejszymi od występujących w Polsce w jakimkolwiek momencie po roku 1956. W okresie tym pojawił się socjologiczny drugi obieg. Pod koniec lat 80. rozpoczęła się nieśmiała odwilż, jednak socjologia czeska po roku 1989 musiała być niemal tworzona od nowa. Kluczową rolę odegrali w tym procesie uczeni do niedawna zepchnięci na margines czy odsunięci od socjologii akademickiej, tacy jak Jiří Musil czy Miloslav Petrusek, bodaj najważniejszy nauczyciel polistopadowego pokolenia socjologów. Trzon młodszej kadry naukowej to osoby, które otrzymały edukację naukowa w okresie „normalizacji”, jak chociażby Jan Keller (ur. 1955) czy Jiř́ Šubrt (ur. 1958), którzy łatwo odnaleźli się w nowej sytuacji. Odbudowa była szybka i skuteczna, a obecny poziom czeskiej socjologii nie odbiega od stanu i statusu socjologii w Polsce, choć ma niewiele postaci zajmujących równie eksponowane, co niektórzy Polacy, pozycje w międzynarodowym życiu naukowym.

$\mathrm{Na}$ pierwszy rzut oka kontekst rozwoju i dzieje socjologii w Polsce i w Czechach wydają się podobne. I tu, i tam narodziła się ona w łonie zbiorowości pozbawionych własnej państwowości, instytucjonalizując się w okresie międzywojennym. Zbliżone jest też doświadczenie komunizmu, likwidacji oraz odbudowy socjologii, po roku 1989 zaś uwolnienie od politycznego nadzoru. W obu przypadkach medium edukacji profesjonalnej i większości twórczości naukowej był język lokalny. Analogiczne jest również położenie poza centrami światowej socjologii i zależny charakter rozwoju, skutkujący dostrzeżona już przez Jana Stanisława Bystronia (1917: 192-193) nieciagłością rodzimych tradycji socjologicznych. Okoliczności sprawiły, że łatwiej dostrzegalna jest ona w socjologii czeskiej niż polskiej.

Nie od rzeczy będzie jednak wskazać istotne różnice w charakterze rozwoju nauki w obu krajach. Po pierwsze, odmienny był kontekst polityczny narodzin dyscypliny. „Kwestia czeska” przełomu XIX i XX wieku oznaczała czeskie roszczenie do polityczno-administracyjnej jedności spójnych terytorialnie ziem Korony św. Wacława i przekucia faktycznej równoprawności czy wręcz dominacji czeskiej ludności w panowanie polityczne czeskich elit. Z kolei słowo „Polska” oznaczało fantomowy byt lub co najwyżej republikę literacka, nawet jeśli ideologiczne okulary niektórych uczonych pokazywały ją jako całość nie mniej realną od społecznych organizmów państw zaborczych (por. Kurczewska 1979: 44-92). Inny był kontekst społeczny: na większości ziem polskich przed i po pierwszej wojnie światowej podstawowy problemem społeczny sta- 
nowiła kwestia chłopska. Przemysł - i w ogóle techniczna i społeczna infrastruktura nowoczesności - były słabo rozwinięte i dopiero pod władzą komunistów rozpoczęto forsowną industrializację. W międzywojennej Czechosłowacji nie tak palącą kwestię chłopską rozwiązano dzięki skutecznej reformie rolnej, a ziemie czeskie zostały uprzemysłowione już w drugiej połowie XIX wieku, choć główną rolę odgrywały tam mniejsze przedsiębiorstwa ${ }^{4}$. Czechy były zurbanizowane, przy czym, nie liczac Pragi, dominowały w nich niewielkie miasta, a czeskie elity, w tym intelektualne, wywodziły się zazwyczaj z niższych warstw społeczeństwa. Dla Polski charakterystyczny był dystans między mało licznymi, głównie ziemiańskimi i wywodzącymi się ze szlachty elitami a przeważnie chłopskimi masami ludowymi.

Czynniki strukturalne określały do pewnego stopnia także głębokość intelektualnego zaplecza i wielkość publiczności socjologicznej. System edukacji był na ziemiach czeskich rozwinięty, audytorium literackie i naukowe liczne, a rynek książkowy bogaty. Podłoże intelektualne, na którym wyrastała socjologia (i do której mogła trafiać popularna twórczość naukowa), było co do skali zbliżone do polskiej publiczności, nie odpowiadając stosunkowi liczby ludności obu krajów. Warto dodać, że proporcje liczebności publiczności literackiej wyrównywały się powoli, a odsetek studentów wyraźnie zmienił się na korzyść Polski dopiero w latach 70. XX wieku ${ }^{5}$. Warto też dodać, że u progu minionego stulecia uniwersytet w Pradze był prawdziwym centrum czeskiego życia intelektualnego - podobnej roli nie odgrywał wówczas ani potem żaden z polskich uniwersytetów. Pośrednią tego konsekwencję stanowi fakt, że wywodzący się z Polski intelektualiści zdobywali renomę raczej

\footnotetext{
${ }^{4}$ Choć poziom rozwoju i struktura społeczna uważanej za bardziej tradycjonalistyczną Słowacji były zbliżone do polskich, to i tam stosunki społeczne były bardziej demokratyczne niż w Polsce. 5 W roku 1930 opublikowano w Polsce 5271 tytułów (Kubiczek 1992: 223), w Czechosłowacji zaś 5878, w tym w języku czeskim i słowackim 4859 („Statistická ročenka Republiky československé” 1934: 240). W roku 1960 wydano w Polsce 6879 tytułów o łącznym nakładzie 92,3 mln. egzemplarzy, a w 1990 - 10242 pozycji w 175,6 mln. egzemplarzy (Kubiczek 1992: 223). W roku 1960 w Czechosłowacji opublikowano 5818 pozycji o łącznym nakładzie 48,5 mln. egzemplarzy, z czego na ziemiach czeskich odpowiednio: 4147 i 38,2 mln. („Statistická ročenka ČSSR” 1963: 461). W roku 1987 wydano ich tam 7067 w nakładzie 105,8 mln., w tym w Czechach odpowiednio: 4907 i 73,9 mln. („Statistická ročenka Československé socialistické republiky” 1988: 593). Jeśli chodzi o liczbę studentów, to w r. akad. 1930/31 studiowało ich w Polsce 48,2 tys., w r. 1960/61 - 165,7 tys., a w r. 1990/91 - 394,3 tys. (Kubiczek 1992: 177). W Czechosłowacji w r. akad. 1931/32 studiowało 34,1 tys. osób („Statistická ročenka Republiky československé” 1934: 229-230), w r. akad. 1960/61 - 94 tys. (w Czechach - 64,4 tys.; „Statistická ročenka ČSSR” 1963: 415), a w r. 1987/88 169,8 tys. (z czego w Czechach 112 tys.) („Statistická ročenka Československé socialistické republiky” 1988: 584).
} 
(w późniejszym okresie: również) poza granicami kraju, co było nie bez znaczenia dla międzynarodowej recepcji polskiej socjologii.

\section{/// Polsko-czeskie stosunki naukowe, ich charakter i dynamika}

Historia wzajemnych relacji i wymiany idei między polskimi a czeskimi socjologami (lub szerzej: myślicielami społecznymi) sięga bodaj początków dyscypliny. Jak się zdaje, czescy intelektualiści na ogół znali najważniejsze postacie polskiego życia duchowego; u Polaków znajomość Czech bywała rzadsza, choć skala ich ciekawości i wiedzy o sąsiadach bywała zróżnicowana.

Jeśli skupić się na dziejach socjologii pojmowanej jako posiadająca dystynktywną tożsamość i elementarne instytucje dyscyplina naukowa, to w historii relacji polsko-czeskich można wyróżnić pięć faz. Pierwsza z nich obejmuje okres od narodzin do likwidacji akademickiej socjologii u progu lat 50. XX wieku. Niezła miara wzajemnego zainteresowania jest zawartość czasopism - opublikowane artykuły i recenzje prac socjologów z sąsiedniego kraju. Jeśli chodzi o Czechosłowację, to już w roku 1922 w piśmie „Parlament” ukazała się skrócona wersja znanego przeglądu polskiej twórczości socjologicznej pióra Jana Stanisława Bystronia (1922: 373-377). Co ciekawe, nie zawierała ona fragmentu, w którym mowa była o lokalnej specyfice i nieciągłości rozwoju dyscypliny. W pierwszym roczniku „Sociologickej revui”, organie „szkoły brneńskiej”, jednej z dwóch skonfliktowanych grup socjologów czechosłowackich, ukazał się kolejny, dwuczęściowy przegląd socjologii polskiej autorstwa Franciszka Mirka (1930), kilka zaś lat później - inny artykuł tego autora (Mirek 1934). Pismo to aż do likwidacji u progu lat 50. XX wieku systematycznie publikowało recenzje prac Antoniego Żabko-Potapowicza (13 pozycji, on sam także napisał dla pisma kilka recenzji), polskich i amerykańskich dzieł Znanieckiego (7 tytułów), książek Mirka, Chałasińskiego, Krzywickiego (jego artykuł ukazał się w powojennych numerach pisma: Krzywicki 1948-1949) i innych, mniej dziś znanych uczonych (tab. 1). Autorem większości był redaktor naczelny, a zarazem najbardziej pracowity z recenzentów pisma, Inocenc Arnošt Bláha. „Sociální problémy”, pismo konkurencyjnej „szkoły praskiej”, w odróżnieniu od „Brna” aspirującej do ścisłego profesjonalizmu i głoszącej pochwałę czystej nauki, niemal nie wykazywało zainteresowania polskim życiem naukowym. 
Tab. 1. Recenzowane publikacje, artykuły polskich czeskich i słowackich autorów w 1. 1930-19496

\begin{tabular}{|l|c|c|c|c|c|c|}
\hline Czasopismo & \multicolumn{2}{|c|}{$\begin{array}{c}\text { \#Przegląd So- } \\
\text { cjologiczny” }\end{array}$} & $\begin{array}{r}\text {,Sociologická } \\
\text { revue” }\end{array}$ & \multicolumn{2}{|c|}{$\begin{array}{c}\text {,Sociální } \\
\text { problémy” }\end{array}$} \\
\hline $\begin{array}{l}\text { Pochodzenie recen- } \\
\text { zowanych publikacji } \\
\text { zagranicznych }\end{array}$ & $\begin{array}{c}1930- \\
1939\end{array}$ & $\begin{array}{c}1946- \\
1948\end{array}$ & $\begin{array}{c}1930- \\
1940\end{array}$ & $\begin{array}{c}1947- \\
1949\end{array}$ & $\begin{array}{c}1931- \\
1939\end{array}$ & 1947 \\
\hline Polskie & nd. & nd. & $8 \%$ & $21 \%$ & $0 \%$ & $0 \%$ \\
\hline Czeskie i słowackie & $2 \%$ & $8 \%$ & nd. & nd. & nd. & nd. \\
\hline $\begin{array}{l}\text { Inne środkowoeuro- } \\
\text { pejskie }\end{array}$ & $0 \%$ & $0 \%$ & $7 \%$ & $1 \%$ & $6 \%$ & $9 \%$ \\
\hline Angielskojęzyczne & $48 \%$ & $56 \%$ & $37 \%$ & $43 \%$ & $46 \%$ & $57 \%$ \\
\hline Niemieckojęzyczne & $37 \%$ & $5 \%$ & $18 \%$ & $12 \%$ & $30 \%$ & $4 \%$ \\
\hline Francuskojęzyczne & $12 \%$ & $8 \%$ & $13 \%$ & $6 \%$ & $17 \%$ & $17 \%$ \\
\hline Radzieckie & $0 \%$ & $22 \%$ & $12 \%$ & $7 \%$ & $0 \%$ & $9 \%$ \\
\hline Inne & $2 \%$ & $1 \%$ & $5 \%$ & $10 \%$ & $0 \%$ & $4 \%$ \\
\hline $\begin{array}{l}\text { Zagraniczne łącznie } \\
\text { (100\%) }\end{array}$ & 126 & 77 & 574 & 100 & 69 & 23 \\
\hline $\begin{array}{l}\text { Recenzowane publika- } \\
\text { cje łącznie }\end{array}$ & 228 & 106 & 1182 & 350 & 174 & 36 \\
\hline $\begin{array}{l}\text { Artykuły polskich au- } \\
\text { torów }\end{array}$ & $\mathrm{nd} \%$ & $\mathrm{nd} \%$ & 2 & 2 & 1 & 0 \\
\hline $\begin{array}{l}\text { Artykuły czeskich } \\
\text { i słowackich autorów }\end{array}$ & 1 & 1 & nd. & nd. & nd. & nd. \\
\hline
\end{tabular}

Jeśli chodzi o stronę polską, to pierwszy rocznik „Przeglądu Socjologicznego” zawierał „eksportowy” artykuł Bláhy (1931) na temat socjologii czeskiej, wydany także jako separatum, w 1947 roku opublikowano jego tekst o socjologii inteligencji (Bláha 1948a), rok później zaś dwa krótkie sprawozdania dotyczące powojennej socjologii czeskiej i słowackiej (Bláha 1948b, Štefánek 1948). Ponadto pismo zamieściło szereg recenzji czeskich

\footnotetext{
Analiza odnosi się do tekstów opublikowanych jako recenzje, z pominięciem artykułów recenzyjnych oraz not bibliograficznych (ich rozróżnienie było niemożliwe w przypadku „Sociologickej revui”; jeśli chodzi o „Przegląd Socjologiczny”, to w analizie uwzględniono przeglądy czasopism). Jednostką analizy jest recenzowany tytuł; w przypadku recenzji zbiorczych maksymalną liczbę uwzględnionych prac ograniczono do trzech.
} 
i słowackich prac i czasopism naukowych (tab. 1); wśród ich autorów byli Mirek, Józef Obrębski i Jan Szczepański. Zainteresowanie Czechosłowacja - w tym zwłaszcza Słowacja - bezspornie wzrosło w okresie powojennym. W obu krajach nie ukazał się przekład żadnej z wydanych w sąsiednim kraju publikacji książkowych.

Warto zauważyć, że recenzowane w Polsce publikacje stanowiły z reguły produkcje „szkoły brneńskiej”, a wzajemność polsko-czechosłowacka opierała się w zasadzie na kontaktach z „Brnem”.

Niespotykaną wcześniej intensywność, ale też wysoce jednostronny charakter uzyskały stosunki polsko-czechosłowackie w drugiej fazie wzajemnych relacji, przypadającej na lata 1956-1970. Mówiąc o międzynarodowych kontaktach naukowych w czasach „realnego socjalizmu”, należy pamiętać, że były one wielowymiarowe. Zasadniczo miały zorganizowany charakter, odbywały się dzięki pośrednictwu oficjalnych instytucji akademickich. To samo można w pewnym sensie powiedzieć o informacjach na temat życia naukowego, takich jak sprawozdania, recenzje czy artykuły publikowane w zagranicznych czasopismach naukowych, nie zawsze odbijające rzeczywiste zainteresowania uczonych. Nie bez znaczenia były jednak trudniejsze do prześledzenia, nieoficjalne kontakty, osobiste przyjaźnie i znajomości, prywatna korespondencja i wymiana książek, a wreszcie samodzielne wyszukiwanie i lektura zagranicznych prac.

Polska inspiracja była odegrała pewną rolę w samych narodzinach nowej socjologii czechosłowackiej, jako że jej zwolennicy prowadzone w Polsce badania nad klasa robotnicza przywoływali jako argument na rzecz badań socjologicznych w Czechosłowacji (Hochfeld 1956, Klofáč 1956). Kontakty między polskimi a czeskimi uczonymi zostały nawiązane już w latach 50. XX wieku. Jan Sedláček, późniejszy tłumacz polskiej literatury naukowej i przyjaciel wielu polskich socjologów, po raz pierwszy odwiedził Warszawę tuż przed polskim Październikiem (Sedláček, Burianek, Šubrt 2000: 18, Kaltenberg-Kwiatkowska 2008: 147). W latach 60. można już mówić o intensywnej współpracy instytucjonalnej (zob. Kilias 2001a). W 1963 roku odbywały się systematyczne wizyty socjologów polskich w Czechosłowacji i czechosłowackich w Polsce. Na pierwszy zjazd socjologów czechosłowackich, który odbył się w listopadzie 1966 roku w Špindlerovym Mlýnie, została zaproszona trzyosobowa delegacja PAN oraz PTS. Jej członkowie przywieźli stamtąd ideę zorganizowania czechosłowacko-polskiej konferencji socjologicznej, największego wspólnego przedsięwzięcia naukowego ([Bauman] 1967: 324)7. Pierwsze spotkanie

\footnotetext{
Biuro PTS: Protokół z zebrania Zarządu Głównego PTS z dnia 9 grudnia 1966 r., s. 1
} 
socjologów czechosłowackich i polskich, zorganizowane przez akademie nauk i towarzystwa socjologiczne obu krajów, odbyło się w kwietniu 1967 roku w Smolenicach pod Bratysława. Brała w nim udział osiemnastoosobowa delegacja polska oraz pięćdziesięcioosobowa reprezentacja socjologii czechosłowackiej. Uczestnicy spotkania postanowili opublikować referaty z konferencji, a także kontynuować podobnego rodzaju spotkania, z których kolejne miało się odbyć się w roku 1969 na terenie Polski (Szostkiewicz 1968). Niestety, na przeszkodzie stanęły wydarzenia polityczne: wydarzenia marcowe w Polsce oraz zdławienie Praskiej Wiosny. W rezultacie marcowej czystki pracę stracił między innymi popularny w Czechosłowacji Zygmunt Bauman, któremu zresztą czescy koledzy złożyli (nieprzyjęta) propozycję podjęcia pracy na Uniwersytecie Karola (Bauman, Petrusek, Reifová 1997: 201). Warto wspomnieć, że Kolegium Filozofii i Socjologii Czechosłowackiej Akademii Nauk oraz Czechosłowackie Towarzystwo Socjologiczne wraz z radą redakcyjną „Sociologickego časopisu” wystosowało oficjalne protesty przeciwko czystkom (Sdělení redakce 1968). Radykalnej zmianie sytuacja uległa po inwazji państw Układu Warszawskiego w sierpniu 1968 roku, oznaczającej zamrożenie formalnych kontaktów, które nigdy nie odzyskały skali, jaką miały w latach 60 .

Jaki charakter miała obecność polskiej twórczości socjologicznej w czechosłowackim a czechosłowackiej w polskim obiegu intelektualnym lat 60. XX wieku? Jak napisał Stefan Szostkiewicz (1968) w swej relacji z konferencji w Smolenicach, Czesi i Słowacy doskonale znali polską literaturę naukowa. Opublikowano kilkanaście przekładów z polskiej literatury naukowej (tab. 2), przy czym najczęściej wydawanymi autorami byli Zygmunt Bauman (trzy tytuły, łącznie sześć wydań), Jan Szczepański (trzy tytuły), Adam Podgórecki (dwa tytuły oraz skrypt będący skrótem trzeciego) i Stefana Szostkiewicza (jeden tytuł, dwa wydania).

Tab. 2. Czechosłowackie i czeskie przekłady polskojęzycznej literatury socjologicznej

\begin{tabular}{|l|c|c|c|c|c|c|}
\hline Lata & $\begin{array}{c}1960- \\
1969\end{array}$ & $\begin{array}{c}1970- \\
1979\end{array}$ & $\begin{array}{c}1980- \\
1989\end{array}$ & $\begin{array}{c}1990- \\
1999\end{array}$ & $\begin{array}{c}2000- \\
2009\end{array}$ & $\begin{array}{c}2010- \\
2014\end{array}$ \\
\hline $\begin{array}{l}\text { Wydania (nie li- } \\
\text { cząc wznowień) }\end{array}$ & $17(14)$ & $3(3)$ & $1(1)$ & $2(2)$ & $8(7)$ & $2(2)$ \\
\hline Lącznie & & & $33(29)$ \\
\hline
\end{tabular}


W latach 1965-69 „Sociologický časopis” wydrukował trzy artykuły polskich autorów oraz sto kilkadziesiąt recenzji, sprawozdań, informacji i not bibliograficznych informujących o polskiej socjologii (tab. 3). Słowacka „Sociológia” w roku 1969 - pierwszym roku istnienia pisma - zamieściła osiem podobnych tekstów.

Tab. 3. „Sociologický časopis”: recenzowane publikacje i artykuły polskich autorów $^{8}$

\begin{tabular}{|c|c|c|c|c|c|c|}
\hline $\begin{array}{l}\text { Pochodzenie re- } \\
\text { cenzowanych } \\
\text { publikacji zagra- } \\
\text { nicznych }\end{array}$ & $\begin{array}{c}1965- \\
1969\end{array}$ & $\begin{array}{c}1970- \\
1979\end{array}$ & $\begin{array}{c}1980- \\
1989\end{array}$ & $\begin{array}{c}1990- \\
1999\end{array}$ & $\begin{array}{c}2000- \\
2009\end{array}$ & $\begin{array}{c}2010- \\
2014\end{array}$ \\
\hline Polskie & $24 \%$ & $14 \%$ & $3 \%$ & $15 \%$ & $9 \%$ & $3 \%$ \\
\hline $\begin{array}{l}\text { Radzieckie, rosyj- } \\
\text { skie, ukraińskie }\end{array}$ & $7 \%$ & $58 \%$ & $65 \%$ & $1 \%$ & $0 \%$ & $0 \%$ \\
\hline $\begin{array}{l}\text { Inne socjalist. (środ- } \\
\text { kowoeur.) }\end{array}$ & $3 \%$ & $5 \%$ & $14 \%$ & $4 \%$ & $4 \%$ & $3 \%$ \\
\hline Angielskojęzyczne & $32 \%$ & $17 \%$ & $15 \%$ & $49 \%$ & $74 \%$ & $95 \%$ \\
\hline $\begin{array}{l}\text { Niemieckojęzyczne } \\
\text { (zachodnie) }\end{array}$ & $19 \%$ & $2 \%$ & $2 \%$ & $15 \%$ & $9 \%$ & $0 \%$ \\
\hline Francuskojęzyczne & $12 \%$ & $3 \%$ & $2 \%$ & $15 \%$ & $4 \%$ & $0 \%$ \\
\hline Inne zachodnie & $0 \%$ & $1 \%$ & $0 \%$ & $1 \%$ & $0 \%$ & $0 \%$ \\
\hline $\begin{array}{l}\text { Zagraniczne łącznie } \\
(100 \%)\end{array}$ & 165 & 166 & 125 & 110 & 159 & 113 \\
\hline $\begin{array}{l}\text { Recenzowane publi- } \\
\text { kacje łącznie }\end{array}$ & 204 & 246 & 248 & 212 & 341 & 224 \\
\hline $\begin{array}{l}\text { Artykuły polskich } \\
\text { autorów }\end{array}$ & 4 & 7 & 2 & 9 & 9 & 3 \\
\hline
\end{tabular}

Ważny jest nie tylko fakt przekładania polskiej literatury czy ilość recenzji, ale przede wszystkim rola, jaką odegrała polska literatura naukowa. Tak dla bardziej doświadczonych uczonych, jak i młodszych adeptów dyscypliny stała się ona bodaj najważniejszym źródłem wiedzy: Zarys socjologii Zygmunta Baumana (1965a; kolejne wydania: 1965b, 1966) uchodził za naj-

8 Dane obejmuja także publikacje w angielskojęzycznej mutacji pisma, „Czech Sociological Review". 
lepszy czeskojęzyczny podręcznik socjologii, pierwszym w Czechosłowacji nowoczesnym podręcznikiem metodologii był słowacki przekład skryptu Stefana Szostkiewicza (1964; drugie, poprawione wydanie: 1965), a słowackie wydanie pracy Jana Szczepańskiego Socjologia. Rozwój problematyki i metod (1967) stało się na kilkanaście lat jedynym dostępnym podręcznikiem klasycznej socjologii.

Polskie zainteresowanie czechosłowacką socjologią było wyraźnie mniejsze. W polskiej prasie fachowej o zasięgu ogólnopolskim - brałem tu pod uwage „Kulturę i Społeczeństwo”, „Przegląd Socjologiczny”, „Studia Socjologiczne” i „Studia Socjologiczno-Polityczne” z lat 1961-1969 - zamieszczono jedynie kilka tekstów dotyczących czeskiej lub słowackiej socjologii i tylko dwa teksty czeskich autorów: „Studia Socjologiczne” opu-

Tab. 4. „Studia Socjologiczne”: recenzowane publikacje i artykuły czeskich oraz słowackich autorów

\begin{tabular}{|l|c|c|c|c|c|c|}
\hline $\begin{array}{l}\text { Pochodzenie } \\
\text { recenzowanych } \\
\text { publikacji } \\
\text { zagranicznych }\end{array}$ & $\begin{array}{c}1960- \\
1969\end{array}$ & $\begin{array}{c}1970- \\
1979\end{array}$ & $\begin{array}{c}1980- \\
1989\end{array}$ & $\begin{array}{c}1990- \\
1999\end{array}$ & $\begin{array}{c}2000- \\
2009\end{array}$ & $\begin{array}{c}2010- \\
2014\end{array}$ \\
\hline Czeskie i słowackie & $0 \%$ & $4 \%$ & $1 \%$ & $7 \%$ & $8 \%$ & $0 \%$ \\
\hline $\begin{array}{l}\text { Radzieckie, rosyj- } \\
\text { skie, ukraińskie }\end{array}$ & $0 \%$ & $25 \%$ & $17 \%$ & $7 \%$ & $8 \%$ & $20 \%$ \\
\hline $\begin{array}{l}\text { Inne socjalist. } \\
\text { (środkowoeur.) }\end{array}$ & $0 \%$ & $14 \%$ & $5 \%$ & $0 \%$ & $0 \%$ & $0 \%$ \\
\hline Angielskojęzyczne & $100 \%$ & $39 \%$ & $59 \%$ & $74 \%$ & $77 \%$ & $80 \%$ \\
\hline $\begin{array}{l}\text { Niemieckojęzyczne } \\
\text { (zachodnie) }\end{array}$ & $0 \%$ & $7 \%$ & $9 \%$ & $7 \%$ & $8 \%$ & $0 \%$ \\
\hline Francuskojęzyczne & $0 \%$ & $11 \%$ & $7 \%$ & $4 \%$ & $0 \%$ & $0 \%$ \\
\hline $\begin{array}{l}\text { Inne zachodnie } \\
\text { Zagraniczne łącznie }\end{array}$ & 1 & 28 & 82 & 27 & 13 & 5 \\
\hline $\begin{array}{l}\text { (100\%) } \\
\text { Recenzowane publi- } \\
\text { kacje łącznie }\end{array}$ & 228 & 268 & 249 & 136 & 104 & 46 \\
\hline $\begin{array}{l}\text { Artykuły czeskich } \\
\text { rów }\end{array}$ & 1 & 2 & 0 & 0 & $0 \%$ & 0 \\
\hline
\end{tabular}


blikowały notatkę Jana Macků (1968) o socjologii czechosowackiej, a ostatni, wydany w 1968 roku numer „Studiów Socjologiczno-Politycznych” zawierał tekst referatu Pavla Machonina (1968) ze zjazdu socjologicznego w Evian (tab. 4, 5).

Tab. 5. „Kultura i Społeczeństwo”: recenzowane publikacje, artykuły czeskich i słowackich autorów

\begin{tabular}{|l|c|c|c|c|c|c|}
\hline $\begin{array}{l}\text { Pochodzenie } \\
\text { recenzowanych } \\
\text { publikacji } \\
\text { zagranicznych }\end{array}$ & $\begin{array}{c}1960- \\
1969\end{array}$ & $\begin{array}{c}1970- \\
1979\end{array}$ & $\begin{array}{c}1980- \\
1989\end{array}$ & $\begin{array}{c}1990- \\
1999\end{array}$ & $\begin{array}{c}\mathbf{2 0 0 0}- \\
\mathbf{2 0 0 9}\end{array}$ & $\begin{array}{c}2010- \\
\mathbf{2 0 1 4}\end{array}$ \\
\hline Czeskie i słowackie & $3 \%$ & $0 \%$ & $0 \%$ & $1 \%$ & $4 \%$ & $4 \%$ \\
\hline $\begin{array}{l}\text { Radzieckie, rosyj- } \\
\text { skie, ukraińskie }\end{array}$ & $11 \%$ & $5 \%$ & $8 \%$ & $4 \%$ & $3 \%$ & $0 \%$ \\
\hline $\begin{array}{l}\text { Inne socjalist. } \\
\text { (środkowoeur.) }\end{array}$ & $1 \%$ & $3 \%$ & $0 \%$ & $0 \%$ & $0 \%$ & $0 \%$ \\
\hline Angielskojęzyczne & $51 \%$ & $38 \%$ & $32 \%$ & $48 \%$ & $29 \%$ & $39 \%$ \\
\hline $\begin{array}{l}\text { Niemieckojęzyczne } \\
\text { (zachodnie) }\end{array}$ & $5 \%$ & $1 \%$ & $11 \%$ & $7 \%$ & $4 \%$ & $0 \%$ \\
\hline Francuskojęzyczne & $17 \%$ & $12 \%$ & $12 \%$ & $6 \%$ & $12 \%$ & $0 \%$ \\
\hline Inne zachodnie & $0 \%$ & $7 \%$ & $4 \%$ & $3 \%$ & $1 \%$ & $0 \%$ \\
\hline $\begin{array}{l}\text { Zagraniczne łącznie } \\
\text { (100\%) }\end{array}$ & 121 & 74 & 84 & 69 & 73 & 23 \\
\hline $\begin{array}{l}\text { Recenzowane publi- } \\
\text { kacje łącznie }\end{array}$ & 307 & 205 & 121 & 188 & 157 & 72 \\
\hline $\begin{array}{l}\text { Artykuły czeskich } \\
\text { i słowackich auto- } \\
\text { rów }\end{array}$ & 0 & 0 & 0 & 0 & 0 & 0 \\
\hline
\end{tabular}

Nie było w polskiej prasie fachowej żadnej reakcji na dwa najważniejsze dzieła czeskich nauk społecznych: na poświęconą społeczeństwu postindustrialnemu interdyscyplinarną Civilizace na rozcesti zespołu Radovana Richty, która jednak została przetłumaczona na język polski (Richta 1966, 1971)', ani na Ceskoslovenske společnost zespołu Machonina (1969); co prawda,

9 Jako bodaj jedyna czeskojęzyczna książkowa publikacja naukowa zbliżona problematyką do socjologii. 
książka ta ukazała się dopiero pod koniec roku 1969, a jej charakter wykluczał, by mogła zostać zreferowana w pomarcowej Polsce. Wyjątkiem były „Roczniki Socjologii Wsi”, w których w latach 1965-1969 pojawiło się 10 relacji bądź recenzji czeskich i słowackich książek i czasopism.

Postępująca od końca lat 60. XX wieku Husákowska ,normalizacja” oznaczała ograniczenie kontaktów zagranicznych czechosłowackich uczonych, przede wszystkim z Zachodem, ale także z Polską. Wyrazem tego był spadek oficjalnego zainteresowania polską socjologia, o której referowano teraz znacznie rzadziej, więcej miejsca poświęcając nauce w innych krajach socjalistycznych, w tym zwłaszcza w Związku Radzieckim (tab. 3). Rzecz jasna, podobna reorientacja była możliwa także dzięki rozwojowi socjologii w krajach socjalistycznych. Jego ślad stanowią publikowane także w Polsce przekłady i recenzje, głównie radzieckich prac naukowych (tab. 4 i 5). Za symboliczny wyznacznik zaistnienia środkowo- i wschodnioeuropejskiej, (z nazwy) marksistowskiej socjologii jako realnego zjawiska, a nie ogólnej idei lub - jak to wcześniej bywało - przeznaczonej na pokaz atrapy, można uznać siódmy międzynarodowy zjazd socjologiczny, który odbył się w roku $1970 \mathrm{w}$ Warnie.

Warneński zjazd można uznać za moment otwierający trzecią fazę polsko-czechosłowackich relacji naukowych. Stały się one wówczas mniej intensywne, zwłaszcza te sformalizowane. Zaplanowane pierwotnie na rok 1969 drugie spotkanie polsko-czeskie ostatecznie odbyło się dopiero w 1973 roku. Choć rzadziej, to nadal ukazywały się recenzje, a nawet przekłady polskich prac, jak tłumaczenie Utopii Jerzego Szackiego (1971), ostatnie echo fali przekładowej z lat 60., czy o cztery lata późniejszy przekład podręcznika metodologii Stefana Nowaka (1975). Nie oznaczało to braku nieoficjalnego zainteresowania polską socjologią, która czasem okazywała się jedynym „oknem na świat” czeskich i słowackich socjologów. W kontekście izolowanej i zdeprofesjonalizowanej socjologii czeskiej - i w ogóle zglajszachtowanego życia intelektualnego - istotną rolę odgrywały nie tylko publikacje ściśle socjologiczne, ale twórczość polskiej humanistyki i nauk społecznych, nie wspominając o przekładach z literatur zachodnich. W latach 80 . nauka polska ponownie znalazła się na cenzurowanym, a i indywidualne kontakty stały się trudniejsze. Charakterystyczne, że gdy pojawił się pomysł czeskiego przekładu Historii myśli socjologicænej Jerzego Szackiego, którego chciał się podjać Jan Sedláček, spotkał się on z nieprzychylnym przyjęciem. Stało się tak tyleż wskutek wątpliwości ideologicznych co do prawomyślności polskiego autora, ile niekorzystnej pozycji tłumacza, 
osłabionej wskutek reperkusji listu, a w istocie donosu Ryszarda Dyoniziaka, informującego redakcje „Sociologickégo časopisu”, że przychylnie zrecenzowana tam przez Sedláčka praca Jerzego J. Wiatra Marksistowska teoria rozwoju społecznego, przedmiot partyjnej dyskusji i krytyki, została w Polsce negatywnie oceniona (Sedláček 2003-2008, Wiatr 2008: 92-93). Co równie charakterystyczne, zamiast dzieła Szackiego przełożono ostatecznie wartościowy, trzyczęściowy radziecki przegląd dorobku socjologii zachodniej (Kon 1982, Komarov 1983, Konstantinov 1981).

Po roku 1989 nastapiła odbudowa socjologii czeskiej, w której Polacy nie odegrali istotnej roli, jako że uczeni obu krajów zwrócili się zdecydowanie ku Zachodowi, skąd płynęły nie tylko idee, ale także pieniądze na stypendia czy wspólne przedsięwzięcia badawcze. I czescy, i polscy partnerzy najwięcej uwagi poświęcali łatwiejszym niż kiedykolwiek przedtem kontaktom z Zachodem. Moment ten stanowi początek kolejnej fazy w polsko-czeskich stosunkach naukowych. Jej początek oznaczał załamanie, które z czasem przerodziło się w stagnację. Wzajemne stosunki zostały z dnia na dzień zdecentralizowane i nieco odbiurokratyzowane, ale służące im formy instytucjonalne nie przeżyły reorganizacji nauki i szkolnictwa wyższego. Rozpadł się także międzynarodowy rynek księgarski krajów socjalistycznych, w rezultacie czego na początku lat 90 . pojawiły się nawet problemy z prenumeratą regularnie dotąd przychodzących czasopism. W tej sytuacji jedynym dostępnym źródłem literatury z sąsiednich krajów stały się prywatne kontakty. Nie było nowych przekładów polskich prac, a choć były one nadal recenzowane, to dwie trzecie z opublikowanych po roku 1990 recenzji było dziełem dwóch polonofilów, których kariery naukowe rozpoczęły się w latach 60. XX wieku. Niemal dwadzieścia napisał Jan Sedláček (1935-2008), obok Jiř́íego Musila jeden z dwóch wywodzących się z Czech honorowych członków Polskiego Towarzystwa Socjologicznego, na nowo bardziej aktywny na tym polu po okresie milczenia w latach 70. i 80., autorem kilku był zaś Miloslav Petrusek (1936-2012). Z czasem stworzono substytuty nieistniejącego rynku i elementarne formy współpracy instytucjonalnej, jednak utrzymywanie wzajemnych stosunków było droższe niż w czasach socjalizmu, co przy umiarkowanym zainteresowaniu oznaczało spadek ich intensywności.

Rozpad Czechosłowacji nic wpłynął w istotny sposób na charakter wzajemnych relacji, pewne znaczenie miała jednak dla nich integracja europejska, w tym uruchomiony w roku akademickim 1997/1998 program Erasmus. Umożliwił on finansowanie wymiany studentów i nauczycieli 
akademickich, a choć oferowane w nim środki były niewielkie, można je było przeznaczyć na finansowanie ruchu akademików w kierunku innym niż Wschód-Zachód. Wraz z poprawą sytuacji gospodarczej tańsze niż poprzednio stało się utrzymywanie wzajemnych relacji. Kolejnym czynnikiem, który przyczynił się do odbudowy na nowych podstawach polsko-czeskich kontaktów naukowych, stała się deregulacja i prywatyzacja oświaty wyższej w Polsce, a zwłaszcza w Czechach, po uchwaleniu tam w 1998 roku nowej ustawy o szkolnictwie wyższym. Jej skutkiem było powstanie nowych uczelni, które chcąc spełnić biurokratyczne wymogi odnoszące się do otwierania i prowadzenia studiów, poszukiwały kadry naukowej, a wobec jej niedoboru w kraju - także za granica. Stworzyło to zapotrzebowanie na uczonych z sąsiadujących krajów, niekoniecznie najwybitniejszych, za to gotowych przyjeżdżać na zajęcia. Czynniki te w połowie pierwszej dekady nowego wieku przyczyniły się do stopniowego ożywienia kontaktów, tak że można mówić o kolejnej, piątej fazie wzajemnych relacji. Co znamienne, zmieniły się sposoby i charakter kontaktów, w których większą rolę zaczęły odgrywać ośrodki położone bliżej granicy aniżeli dość od niej odległe Warszawa i Praga, przede wszystkim z polskiej i czeskiej części Śląska. Pojawiły się badania transgraniczne. W tym okresie ponownie pojawiły się przekłady, po części książek autorów uznanych jako socjologiczni analitycy problemów regionu Europy Środkowo-Wschodniej, takich jak Jadwiga Staniszkis (2006, 2009) czy Zdzisław Krasnodębski (2006), po części zaś popularne prace i podręczniki uznanych autorów, jak książka Piotra Sztompki (2007) o socjologii wizualnej czy Socjologia ekonomiczna Witolda Morawskiego (2005). Trwałym fenomenem jest zainteresowanie twórczością niemieszkającego w Polsce i piszącego po angielsku Zygmunta Baumana, uhonorowanego w roku 2006 roku Nagrodą Václava Havla.

Wzajemne stosunki cechuje trwała asymetria: po roku 1989 opublikowano w Polsce niewiele recenzji czeskich prac naukowych (tab. 4 i 5) i nie wydawano przekładów czeskich książek socjologicznych. Warto jednak wspomnieć o aktywności czołowego polskiego historyka socjologii, Włodzimierza Wincławskiego, autora ważnej pracy o dziejach socjologii słowackiej (1991), pod którego kierownictwem powstawały prace magisterskie o historii socjologii czeskiej, oraz o publikacji numeru „Polish Sociological Review" (2008) złożonego z tekstów czeskich autorów. Także ja sam opublikowałem kilka prac na temat dziejów socjologii czeskiej (Kilias 2000, 2001b, 2012). Na ogół jednak polscy uczeni niewiele wiedzą o czeskim życiu naukowym. 


\section{/// Wzajemne relacje a wzajemna recepcja, wędrówka idei i pojęć}

Powyższa opowieść o polsko-czeskich kontaktach naukowych, recenzjach i tłumaczeniach nie stanowi, rzecz jasna, dziejów recepcji socjologii polskiej w Czechach (lub na odwrót) ani tym bardziej historii ich wzajemnego wpływu. Ich zbadanie wymagałoby pogłębionej analizy czeskiej (polskiej) twórczości naukowej, tymczasem zaś mogę zaoferować jedynie nieuporządkowane spostrzeżenia i impresje. Po pierwsze, jak wskazują przytoczone dane, trudno mówić o jakimkolwiek oddziaływaniu idei socjologii czeskiej na naukę polską. Choć sugerowałyby one istnienie dość systematycznej wędrówki idei w przeciwną stronę, wniosek taki byłby pochopny. Dorobek socjologii polskiej nie stanowił przedmiotu debaty ani nie był wykorzystywany w dyskusjach toczonych w socjologii czeskiej. Nauka polska nie była uważana za nosicielkę szczególnie oryginalnych i niedostępnych gdzie indziej idei. Za przykład mogą pod tym względem posłużyć chociażby dociekania nad narodem, od czasu Bystronia uchodzące w Polsce za specjalność rodzimej socjologii. Choć uczeni czescy, zwłaszcza u progu niepodległości, sami byli zainteresowani podobną tematyką ${ }^{10}$, pisząc o niej nie przywoływali dorobku Polaków, najwyraźniej nie traktując go jako ważnej inspiracji (Kilias 2000). Najważniejszą z metod badawczych socjologii polskiej okresu międzywojennego była bezspornie metoda biograficzna. Tutejsi uczeni z upodobaniem się nią posługiwali, gorliwie zbierając i analizując - prawdę mówiąc, nierzadko bardziej go referując niż poddając analizie socjologicznej - materiał pamiętnikarski. Choć Czesi musieli znać prace oparte na wykorzystaniu pamiętników, próżno w nauce czeskiej szukać próby jej zastosowania...

Inaczej rzecz się oczywiście miała w latach 60. XX wieku, okresie największego zainteresowania nauką polską. Polskie prace były wówczas nie tylko wydawane i czytane, ale także wykorzystywane w dydaktyce, w istotnym stopniu wpływając na charakter wiedzy i przekonań naukowych całej generacji czechosłowackich uczonych. Warto jednak zwrócić uwage, że tym, czego czescy partnerzy szukali w nauce polskiej, były nie tyle oryginalne idee, stanowiące własny dorobek nauki polskiej, ile zdobycze teoretyczne i metodologiczne nauki zachodniej, do której mieli trudniejszy dostęp. Ich zainteresowanie budził więc raczej fakt przeniesienia w kontekst lokalnej (marksistowskiej) socjologii oraz aplikacji do lokalnej

10 Biuro PTS: Protokoły z zebrań Zarządu Głównego PTS z dnia 28 października 1969 r., 29 czerwca 1970 r., 16 grudnia 1971 roku i 9 czerwca 1972 r. 
problematyki (uniwersalnych?) instrumentów socjologii niż swoistość polskich nauk społecznych. Dowodem na to jest sposób doboru partnerów - skupienie się na najnowszej twórczości i na autorach mających najżywszy kontakt z nauką zachodnią, ujmując rzecz lapidarnie: na Szczepańskim i Baumanie raczej niż na Ossowskim i Chałasińskim. Choć współczesne zainteresowanie autorami takimi jak Staniszkis czy Krasnodębski dowodzi, że nauka sąsiadującego kraju może być ważna także jako źródło idei lokalnych, to jego mniejsza skala pokazuje, że ich poszukiwanie stanowiło margines czechosłowackiego zainteresowania socjologia polska. Konstatacji tej nie podważa recepcja dzieła Zygmunta Baumana, które bezspornie oddziaływało chociażby na twórczość Miloslava Petruska (np. 2006). Jego zręby powstały poza kontekstem nauki polskiej, a jego główne prace opublikowano na Zachodzie.

\section{/// Czynniki kształtujące wzajemne relacje: ekologia nauk społecznych}

Jak widać, kontakty, a nawet współpraca między polskimi i czeskimi socjologami były prawdopodobnie bardziej intensywne niz kontakty z uczonymi z jakiegokolwiek innego kraju Europy Środkowo-Wschodniej. Bywały okresy, gdy były szczególnie nasilone, znacząco wpływając na rozwój nauki - przede wszystkim w Czechach, jako że często cechowała je pewna jednostronność. Godna wyjaśnienia jest zarówno skala czeskiego zainteresowania socjologia sąsiedniego kraju, jak i asymetria wzajemnych relacji.

Analizę czynników wpływających na siłę i charakter wzajemnych związków warto rozpocząc od przesłanek natury strukturalnej - od geografii i polityki - po układ sił w nauce światowej. Teoretycznie, sąsiedztwo sprzyja kontaktom, czyniąc krótszymi i tańszymi podróże zagraniczne. Co nie mniej istotne, czyni ono prawdopodobna obecność podobnych problemów społecznych, a nawet wspólnoty doświadczenia zbiorowego. Jak próbowałem pokazać, czeskie i polskie życie społeczne cechowały tyleż podobieństwa, ile różnice, można jednak znaleźć dwa doświadczenia, które przyczyniały się do zainteresowania sąsiednim krajem. Najważniejszym z nich były komunizm oraz marksizm, pojmowane przede wszystkim jako doświadczenie określonej generacji uczonych; do kwestii tej przyjdzie mi jeszcze wrócić. Na mniejszą skalę podobna rolę odegrała transformacja ustrojowa, która wpłynęła na odbiór socjologii (jedynie) polskiej (i tylko) 
w Czechach, zwłaszcza bezpośrednio po roku $1989^{11}$. W pewnym stopniu i tylko dla niektórych uczonych wspólnym tematem była - mimo odmiennej natury kwestii agrarnej w Czechach - problematyka chłopska oraz ideologia agraryzmu ${ }^{12}$. Rzecz jasna, sąsiedztwo umożliwia wspólne badania dotyczące problematyki regionalnej lub transgranicznej. Wiele zależy oczywiście od wzajemnych stosunków politycznych, te zaś w przypadku Polski i Czechosłowacji nie zawsze były przyjazne; rządy komunistów oznaczały z kolei reglamentację wszelkich kontaktów międzynarodowych. Warto też zauważyć, że idee wytwarzane w sąsiadujących, ale posługujących się różnymi językami krajach nie są istotnie uprzywilejowane, jako że publikowane w nich prace rzadko bywają łatwiej dostępne niż produkcja w popularnych językach światowych.

Ważniejsze dla wyjaśnienia skali i charakteru zainteresowania dorobkiem dyscypliny w sąsiednim kraju wydają się dwa inne czynniki. Pierwszy z nich, tyleż oczywisty, ile trudny do uchwycenia, to względna wielkość potencjału naukowego (instytucjonalnego, intelektualnego...). Drugi to układ sił w nauce światowej i sposób jej funkcjonowania - to, czy i w jakim stopniu międzynarodowy obieg naukowy zdominowany jest przez jakieś bliższe lub odleglejsze centrum (centra).

Jak próbowałem pokazać, stosunek potencjałów socjologii polskiej i czeskiej (czechosłowackiej) był zmienny. Dzięki głębokiemu zapleczu intelektualnemu, skali i solidnej instytucjonalizacji dyscypliny był on aż do progu lat 50. XX wieku wyrównany. Przed przejęciem pełni władzy przez komunistów polska twórczość nie była bogatsza ani mimo obecności uczonego światowej sławy, Floriana Znanieckiego, nie miała wyższej przeciętnej wartości naukowej niż prace czeskich kolegów. Dekadę później szala gwałtownie przechyliła się na stronę nauki polskiej, która uzyskała realna przewagę jakościową i ilościową. W przeciwieństwie do pierwszej, druga do dziś pozostaje widoczna. Jeśli zaś chodzi o międzynarodowy kontekst relacji polsko-czeskich, to ulegał on kilkakrotnej zmianie. W okresie międzywojennym trudno mówić o dominacji w europejskiej socjologii jakiegoś pojedynczego centrum, a naukę tę uprawiano na wiele sposobów w wielu (choć dalece nie wszystkich!) krajach Europy. Nie należy jednak lekceważyć wpływu socjologii amerykańskiej, stanowiącej wzór nauki prawdziwie

\footnotetext{
${ }_{11}$ Napisaną kilkanaście lat po tekście polskiego autora historię socjologii czechosłowackiej pióra Inocenca Arnošta Bláhy również otwiera spostrzeżenie o naczelnej roli problematyki narodu oraz opis dociekań jej dotyczących (dodatkowo rozbudowane w późniejszej wersji tekstu: Bláha 1997). 12 Siedem spośród dziewięciu polskich artykułów opublikowanych w „Sociologickým časopisie” w latach 90. XX wieku ukazało się w latach 1990-1994.
} 
empirycznej, której oddziaływanie wspierały finansowo instytucje niemające europejskiego odpowiednika - fundacje, na czele z fundacjami Rockefellerów, świadomie propagującymi tamtejsze wzory uprawiania nauki (Labbé 2011, Skovajsa 2014). Ten styl uprawiania nauki miał otwartych zwolenników zwłaszcza w wśród czeskich uczonych ,szkoły praskiej” (Machotka 1938), ale jego oddziaływanie było szersze, nawet jeśli amerykańska dominacja nie była jeszcze tak oczywista, jak po drugiej wojnie światowej (por. tab. 1). Wówczas to Stany Zjednoczone stały się niezaprzeczalnym centrum intelektualnym, instytucjonalnym i finansowym światowych nauk społecznych, angielski został ich lingua franca, a odradzająca się z kilkuletniego niebytu (w polskim przypadku: zaledwie nieobecności) polska i czechosłowacka socjologia znalazły się na peryferiach (czy półperyferiach) nauki zachodniej. O ile jednak nauka czeska pozostawała niemal odcięta od Zachodu, o tyle Polska szybko zajęła pozycję w pobliżu centrum.

Teoretycznie socjologia zachodnia, z przodującą amerykańską na czele, nie stanowiła jedynego centrum nauk społecznych. We wstępie do książki Main Currents in Sociological Thought Raymond Aron (1976: 14-15) wskazał, że jednym z powodów jej napisania było doświadczenie obecności w międzynarodowych gremiach naukowych, gdzie był świadkiem zderzania się dwóch tradycji socjologicznych, marksistowskiej i zachodniej, którą ówcześni marksiści nazywali nierzadko „burżuazyjną". Wschodnio- i środkowoeuropejskie opowieści o historii myśli socjologicznej rysowały nieraz obraz dwóch odrębnych i obcych sobie tradycji socjologicznych (Vaněk 1981b: 5). $\mathrm{W}$ istocie wspomniane prace reprodukowały wciąż tę sama, mimo upływu kilkudziesięciu lat zasadniczo niezmienną, poststalinowska (czy neostalinowska) wizję socjologii marksistowskiej jako dziedziczki odrębnej spuścizny teoretycznej, posiadającej własny ład przestrzenny, z centrum najpewniej nie w Stanach Zjednoczonych, a w Związku Radzieckim. Kłopot w tym, że faktyczny stan wschodnio- i środkowoeuropejskiej socjologii odbiegał od tego opisu. Socjologia marksistowska, z jaką zetknął się Aron, stanowiła w istocie atrape przeznaczoną na użytek Zachodu, w której miejsce nieobecnych socjologów zajmowali specjaliści od materializmu dialektycznego i/lub oficjele akademiccy (Batygin, Deviatko 1995: 31-34). Faktycznie proces powstawania i instytucjonalizacji tej nauki zaczął się późno i przebiegał z oporami, szczególnie w domniemanym centrum, Związku Radzieckim. Tym niemniej, można mówić o dwóch centrach i dwóch kręgach obiegu naukowego: światowym, w którym centralne miejsce zajmował zamorski hegemon, jak i lokalnym, mającym początkowo czysto 
fantomowy charakter, stopniowo zyskującym na realności, jednak nawet w epoce największego rozkwitu niezdolnym do odegrania niezależnej roli.

O treści wymiany naukowej będzie jeszcze mowa, w tym miejscu warto jednak podkreślić znaczenie ekonomicznego aspektu międzynarodowych stosunków naukowych. Choć fakt, że to zachodni (w praktyce najczęściej: zamorski) partner dysponował środkami pozwalającymi pokryć koszty wymiany naukowej, dawał mu wpływ na jej intensywność i kierunki, istotną rolę w ich kształtowaniu odgrywały w okresie powojennym swoiste problemy ekonomiczne, permanentnie trapiące naukę we wszystkich krajach socjalistycznych. Wyjazdy na Zachód czy zdobywanie tamtejszej literatury utrudniała konieczność uzyskania waluty wymienialnej, do której dostęp był ograniczony. Istotną barierą okazywała się także cena, tak że jedynym sposobem na systematyczne otrzymywanie literatury zachodniej były de facto regularne wyjazdy za granicę. Literatura z krajów socjalistycznych była tańsza i łatwiej dostępna; dotyczy to oczywiście także wyjazdów naukowych.

Niezależnie od problematycznej natury i rzeczywistego znaczenia wschodnio- i środkowoeuropejskiej socjologii marksistowskiej, przynależność do dwóch, teoretycznie konkurencyjnych obiegów naukowych określała charakter i znaczenie relacji polsko-czeskich w najlepszych dla nich latach 60. XX wieku. Powstająca z niebytu socjologia czechosłowacka potrzebowała współczesnej teorii, a zwłaszcza praktycznej umiejętności prowadzenia badań społecznych. Obie te rzeczy najprościej byłoby importować zza „żelaznej kurtyny”. Niestety, czechosłowacka nauka posiadała skromne kontakty zagraniczne, a ich nawiązywanie utrudniały bariery polityczne i ekonomiczne. O drugich już wspominałem, natura zaś tych pierwszych wydaje się oczywista. Zachód był przeciwnikiem w toczącej się „zimnej wojnie", a tamtejsze nauki społeczne postrzegano nierzadko jako narzędzie dywersji ideologicznej. Z kolei odrodzona socjologia polska posiadała już stabilne podstawy instytucjonalne i rzeczywisty dorobek, a przede wszystkim zdołała w krótkim czasie przejąć zachodnie know how. Sami amerykańscy organizatorzy wymiany naukowej widzieli w niej pierwszy za „żelazna kurtyna”" przyczólek socjologii zachodniej i krzewicielkę nowoczesnych, empirycznych badań społecznych ${ }^{13}$. W istocie nie miała ona w pierwszej połowie lat 60. XX wieku w krajach socjalistycznych konkurencji. A tym,

\footnotetext{
13 Wystarczy przypomnieć fakt, że najczęściej recenzowanym w „Sociologickej revui” polskim autorem był Żabko-Potopowicz, czy czeskie zainteresowania „Roczników Socjologii Wsi”.
} 
co uczyniło z niej atrakcyjnego partnera Czechów i Słowaków, był tyleż jej (niekoniecznie oryginalny) dorobek, ile względna dostępność.

Dla recepcji socjologii polskiej istotne było nie tylko jej miejsce na bliskich peryferiach nauki zachodniej i jej równoczesna przynależność do socjologii marksistowskiej, ale także znaczenie, jakie podobna pozycja międzynarodowa uzyskała w kontekście dziejów politycznych i intelektualnych Polski i Czechosłowacji. Socjologowie czechosłowaccy mieli dwa szczególne powody, by uznać naukę polską za atrakcyjny wzór do naśladowania. Były nimi wspólnota doświadczenia generacyjnego i marksizm. Najbardziej popularni w Czechach socjologowie polscy, którzy zadzierzgnęli najsilniejsze osobiste więzy z czeskimi kolegami, to - za wyjątkiem Szczepańskiego - członkowie pokolenia urodzonego na przełomie lat 20. i 30., a więc generacji Machonina i innych wiodących osobowości czechosłowackiej socjologii lat 60 . XX wieku. Tak jak tamci, zostali oni naznaczeni doświadczeniem stalinizmu, rozczarowania doń i poszukiwania innej politycznej drogi, bez porzucania marksizmu (wywiad z J. Wiatrem 1995). Jak już bowiem wspominałem, nowa socjologia czeska była marksistowska. Co to jednak w praktyce znaczyło i dlaczego stanowiło przesłankę ułatwiającą recepcję nauki polskiej?

W myśl najwcześniejszej, poststalinowskiej, aczkolwiek w Związku Radzieckim oficjalnie obowiązującej aż do upadku komunizmu koncepcji socjologii marksistowskiej, stanowiła ona dziedziczkę własnej, niedzielonej z socjologia „burżuazyjną” tradycji intelektualnej oraz wytwarzała własny ład przestrzenny, w którym centrum stanowił (prawdopodobnie) Związek Radziecki1 ${ }^{14}$. Artykuły Juliana Hochfelda (Chałubiński 1991: 151-159) czy popularny w Czechach podręcznik jego ucznia Zygmunta Baumana (1965) rysuja jednak zupełnie inny obraz, przedstawiający nie tyle dwie odrębne tradycje naukowe, ile dwa równoprawne, choć nie równowartościowe naukowo nurty teoretyczne jednej socjologii. Taka socjologia marksistowska, określana mianem „marksizmu otwartego”, częstokroć okazywała się na tyle otwarta na socjologię zachodnią, że można się zastanawiać, co w ogóle miała wspólnego z tradycją Marksa i Engelsa. Co ciekawe, sam fakt istnienia podobnego projektu skłaniał uczonych z krajów socjalistycznych do włączania doń także dzieł polskich niemarksistów, jak chociażby twórczości Szczepańskiego. Tak pojmowana polska socjologia marksistowska

\footnotetext{
14 Nie zajmuję się tutaj kwestią relacji materializmu dialektycznego i socjologii, wokół której koncentrowały się wczesne debaty o wschodnioeuropejskiej socjologii marksistowskiej (por. Voříšek 2012: 127-167). Niezależnie od zajmowanego stanowiska ich uczestnicy zakładali zasadniczą odrębność socjologii marksistowskiej od „burżuazyjnej”.
} 


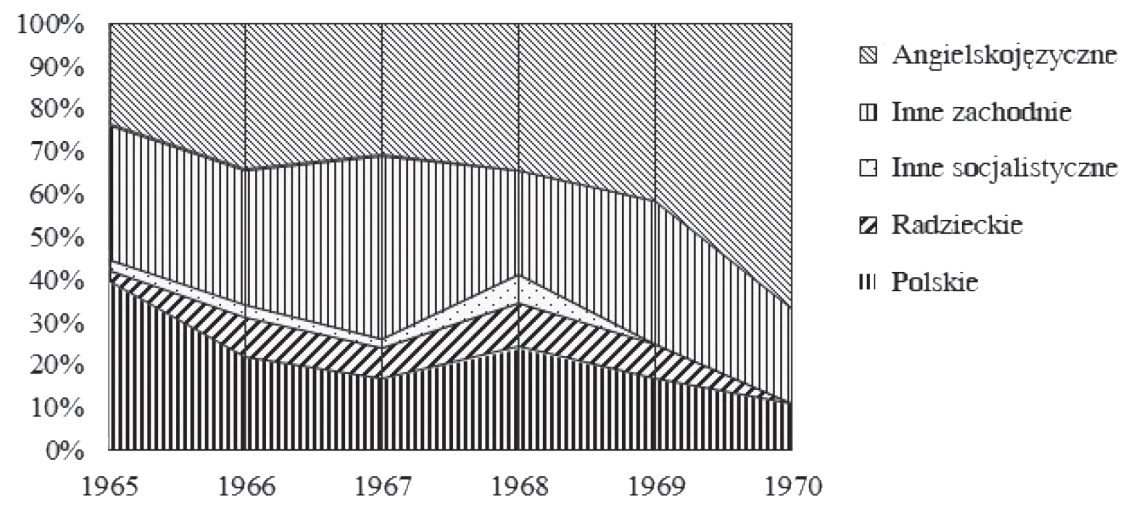

Rys. 1. Pochodzenie publikacji recenzowanych w „Sociologickým časopisie” w 1. 1965-1969

przynależała do socjologii światowej, której centra znajdowały się tam, gdzie rodziły się wiodące idee i skąd płynęły środki finansowe - w Stanach Zjednoczonych raczej niż w Związku Radzieckim! Przejmowane przez nią zachodnie idee i praktyki uzyskiwały jednak ideologiczna prawomocność, stając się składnikami nauki marksistowskiej. Nic więc dziwnego, że z poststalinowskiego i neostalinowskiego punktu widzenia stanowiła ona zagrożenie. Jeśli przyjrzeć się dyskursowi czechosłowackich nauk społecznych lat 60 ., to charakterystyczne dla niego wydaje się wahanie między poststalinizmem a marksizmem otwartym, przy czym o ile ten drugi wydawał się bardziej atrakcyjny, ten pierwszy nie został nigdy otwarcie odrzucony. Zapewne był to także rezultat autocenzury oraz wymogów taktyki politycznej, jednak pisząc o nauce polskiej, czescy autorzy nie zapominali podkreślać, że jest ona en bloc marksistowska. Co ważne, choć jej użyteczność wynikała z deklarowanego (nie przez wszystkich polskich uczonych) marksistowskiego charakteru, to jej faktyczna wartość była efektem przynależności do socjologii zachodniej, z jej zdobyczami teoretycznymi, a zwłaszcza osiąnnięciami badawczymi i metodologicznymi. Ewentualne porzucenie poststalinowskiego dyskursu uczyniłoby polskie pośrednictwo w kontaktach z Zachodem zbędnym. Dowodem na to jest zreszta zmniejszanie się roli polskiej inspiracji w miarę rozwijania przez Czechów i Słowaków własnych kontaktów zagranicznych (por. rys. 1).

Z perspektywy neostalinowskiej koncepcji socjologii marksistowskiej „normalizacja” lat 70. XX wieku była uzasadnionym aktem odrzucenia „marksizmu otwartego” jako konia trojańskiego wrogiej socjologii burżu- 
azyjnej i narzędzia infiltracji socjologii marksistowskiej (por. Vaněk 1981a: 154). Nauka polska stanęła na cenzurowanym jako potencjalny instrument dywersji ideologicznej, mimo że jej obrońcy starali się dowieść jej prawomyślności, na przykład wskazując na uznanie, jakim polska literatura naukowa cieszy się u radzieckich towarzyszy (Sedláček 1971). Reorientacja od socjologii polskiej ku nauce radzieckiej i innych krajów socjalistycznych oznaczała zarazem zwrócenie się ku właściwemu centrum socjologii marksistowskiej. Warto zauważyć, że była ona możliwa dzięki rzeczywistemu rozwojowi wschodnioeuropejskiej, w tym także radzieckiej socjologii, który pozbawił polskie nauki społeczne wyjątkowości.

Upadek komunizmu całkowicie zmienił kontekst międzynarodowy wzajemnych relacji. Wraz z nim nie tylko ostatecznie rozwiała się poststalinowska wizja socjologii marksistowskiej jako alternatywy wobec „nauki burżuazyjnej", ale też rozpadła się wspierająca ją infrastruktura instytucjonalna. Kontakty z Zachodem stały się łatwe jak nigdy dotąd, szczególnie dla cierpiących na ich niedostatek Czechów i Słowaków. Równocześnie instytucjonalny chaos i trudności ekonomiczne nauk społecznych w krajach postsocjalistycznych wzmogły nierównowagę w relacjach między centrum a peryferiami światowych nauk społecznych. Warto jednak zauważyć, że od lat 60. zmieniła się też nauka światowa, w której amerykańska dominacja przestała być tak jednoznaczna. Z perspektywy Polski i Czechosłowacji coraz większą rolę odgrywały życie i instytucje naukowe zjednoczonej Europy, które zaczęły do pewnego stopnia partycypować w finansowaniu lokalnej wymiany akademickiej. Oczywiście, najbardziej renomowani uczeni i prestiżowe instytuty, o pieniądzach nie wspominając, wciąż znajdują się na Zachodzie. Tym niemniej, choć to tam zdobywa się wartościowy kapitał naukowy, nieco łatwiejsze stały się przynoszące różne, pomniejsze korzyści regionalne przedsięwzięcia badawcze czy podróże na północ lub południe (względnie: wizyty przybywających stamtąd gości).

Można wskazać jeszcze jeden mechanizm, dzięki któremu pozycja zajmowana w nauce międzynarodowej wpływała na recepcję twórczości z sąsiedniego kraju. Pozwala on do pewnego stopnia wyjaśnić asymetrię zainteresowania w okresie międzywojennym, kiedy to potencjał i poziom nauki obu krajów były mniej więcej wyrównane. O ile Czesi działali i pu-


wywodzących się z Polski) autorów tworzyło za granica, publikując w językach światowych i będąc obecnymi w międzynarodowym obiegu naukowym. Wystarczy tu wspomnieć Ludwika Gumplowicza czy Floriana

\footnotetext{
15 Wyjątkiem był Tomáš Garrigue Masaryk, który opublikował wiele prac w języku niemieckim.
}

\section{/ 306 STANRZECZY 1[10]/2016}


Znanieckiego, uznaną postać nie tylko polskiego, ale i amerykańskiego życia naukowego, drugiego co do popularności autora polskich publikacji recenzowanych w „Sociologickej revui”" ${ }^{\prime \prime ! ~ J a k ~ s i e ̨ ~ w i e ̨ c ~ w y d a j e, ~ m o z ̇ n a ~ m o ́ w i c ́ ~}$ o interferencji zainteresowania nauką światową i twórczością sąsiedzką czy regionalną. Zjawisko to można zresztą zilustrować, odwołując się do nowszych czeskich przekładów z literatury polskiej. Wśród prac polskich autorów wydanych w Czechach znajdziemy przeglądową pracę Piotra Sztompki (2007) o socjologii wizualnej. Opublikowane mniej więcej w tym samym czasie książki Krzysztofa Olechnickiego (np. 2003) na podobny temat były pewnie nie mniej interesujące, ale to Sztompka jest autorem o globalnej renomie, znanym bardziej z działalności międzynarodowej niż aktywności naukowej na terenie Polski. Z drugiej strony, powodem wydania przekładów prac Jadwigi Staniszkis było najpewniej zainteresowanie ich problematyką, odnoszącą się do regionu, a może także sympatie polityczne wydawców, prawdopodobnie jednak również międzynarodowa renoma autorki.

\section{/// Tradycja intelektualna a kontakty polsko-czechosłowackie}

Oczywiście, spostrzeżenia na temat ekologii i rozwoju instytucjonalnego nauk społecznych nie stanowią kompletnego wyjaśnienia zainteresowania socjologia sąsiedniego kraju i wypada je uzupełnić przynajmniej wzmianką na temat innych przesłanek zainteresowania socjologia polska w Czechach (i mniejszym zainteresowaniem socjologią czeską w Polsce). Trudno nie zauważyć, że do pewnego stopnia wynikają one z natury lokalnego życia intelektualnego. Choć nie sposób scharakteryzować go w kilku słowach, kiedy mowa jest o wzajemnej współpracy i wymianie intelektualnej, warto podkreślić większą zazwyczaj otwartość i zainteresowanie sąsiadami czeskich elit, będące echem dokonanego w XIX wieku, bardziej realistycznego od polskiego rozpoznania własnego potencjału i sytuacji jako narodu małego politycznie i kulturowo (Kilias 1998). Należy do tego dodać mniej lub bardziej pośrednie konsekwencje roli odegranej przez ideę słowiańską w narodzinach nowoczesnej tożsamości czeskiej. Jednym z jej zrębów było przeświadczenie o bliskich więzach kulturowych łączących naród czeski z innymi narodami słowiańskimi i systematyczne zainteresowanie i czerpanie z ich kultur jako źródła, które pozwalało uzupełniać deficyty rodzimej kultury. Idea wzajemności słowiańskiej, której echa wybrzmiewały przynajmniej u części czeskich i słowackich elit intelektualnych jeszcze w okresie międzywojennym, a być nawet może do końca lat

\footnotetext{
${ }_{16}$ Z siedmiu recenzji jego prac trzy dotyczyły publikacji w języku angielskim.
} 
60. XX wieku, przyczyniała się do szczególnego zainteresowaniami kulturą słowiańskich sąsiadów (Št’astný 1968). Jej praktyczny efekt stanowiło szerokie rozpowszechnienie co najmniej biernej znajomości języków słowiańskich. Choć wzajemność nie dotyczyła wyłącznie (ani w pierwszym rzędzie) Polaków, ich język był wyjątkowo bliski, a socjologia akademicka była tu najlepiej rozwinięta. Wśród Polaków zasięg wzajemności słowiańskiej ograniczał się w praktyce do uczonych slawistów. Dzieje idei słowiańskiej w Polsce ujawniaja zresztą pewną osobliwość - niewielkie i wyraźnie instrumentalne zainteresowanie sąsiadami (Mikulka 1984: 155-157), długo - być może po dziś dzień? - miewające w istocie neokolonialny charakter (zob. Sowa 2011). Odnosi się to tak do jego dominujących kierunków, jak i cechującej je postawy paternalizmu. Nastawienie to bez watpienia negatywnie oddziaływało na polsko-czeskie stosunki polityczne w pierwszej połowie XX wieku; rzecz jasna, waga i znaczenie tego czynnika w innych dziedzinach i okresach wymagałaby bardziej szczegółowej analizy.

Tak czy inaczej, odmienność postaw przekłada się na asymetrię kompetencji językowych. Czescy intelektualiści, zwłaszcza starszej daty, często rozumieja język polski, podczas gdy Polacy rzadko choćby biernie władają czeskim. Warto co prawda dodać, że w okresie komunizmu znajomość polskiego miała także praktyczne przesłanki: w rejonach przygranicznych chętnie oglądano ciekawszą wówczas polską telewizję, a zainteresowani polityką częstokroć słuchali niezagłuszanych na terenie Czechosłowacji, polskojęzycznych audycji Radia Wolna Europa.

\section{/// Podsumowanie}

Dzieje wzajemnych relacji socjologów polskich i czeskich (czechosłowackich) to historia dość zazwyczaj intensywnych kontaktów i stosunkowo skromnej recepcji, z wyjątkiem lat 60 . XX wieku, kiedy to polska twórczość socjologiczna odcisnęła silny wpływ na naukę w sąsiadującym kraju. Wzajemne relacje miewały na ogół nieco, a w okresie komunistycznym mocno asymetryczny charakter. Analiza przyczyn tej asymetrii nie dowodzi jednak, by chodziło - jak wierzy wielu zarówno polskich, jak i czeskich uczonych - o naturalny efekt wyższości polskiej socjologii, której przewaga to efekt odmiennych losów dyscypliny w latach 50. XX wieku i później. Skalę nierówności wzajemnych relacji lepiej tłumaczy większa otwartość Czechów, konfiguracja międzynarodowa oraz obecność kilkorga Polaków w międzynarodowym obiegu naukowym. Należy przy tym zauważyć, że 
intensywność kontaktów nie przekładała się, jak się wydaje, na intensywność recepcji wywodzących się z sąsiedniego kraju oryginalnych idei.

Polsko-czeskie relacje naukowe są obecnie dość ożywione i nadal asymetryczne. Trudno oceniać, na ile asymetria ta odpowiada stosunkowi ilościowemu i jakościowemu produkcji naukowej. Warto jednak pamiętać, że poważanie, jakim się do dziś cieszy w Czechach polska socjologia, to przede wszystkim efekt roli odegranej przez nią w latach 60. XX wieku, być może wzmagany dzięki nostalgii coraz mniej już licznych uczonych czeskich pamiętających tamten okres.

Bibliografia:

/// Aron R. 1976. Main Currents in Sociological Thought, t. 1, tłum. R. Howard, H. Weaver, Penguin Books.

/// Batygin G.S., Deviatko I.F. 1995. Metamorfozy socjologii rosyjskiej, [w:] Socjologia Europy Środkowo-Wschodniej 1956-1990, red. J. Mucha, M.F. Keen, tłum. L. Stetkiewicz, J. Mucha, IFiS PAN, s. 25-39.

/// Bauman Z. 1964. Zarys marksistowskiej teorii społeczeństwa, PWN.

/// Bauman Z. 1965a. Sociologie, tłum. A. Měšt’an, I wyd., Orbis.

/// Bauman Z. 1965b. Sociologie, tłum. A. Měšt’an, II wyd., Orbis.

/// Bauman Z. 1966. Sociologie, tłum. A. Měšt’an, III wyd., Orbis.

/// [Bauman Z.] 1967. Pierwsza ogólnokrajowa konferencja socjologów cæechostowackich, „Studia Socjologiczne” nr 2, s. 323-324.

/// Bauman Z., Petrusek M., Reifová I. 1997. Deset otázek profesoru Zygmunta Baumanovi, „Sociologický časopis”, nr XXXIII, s. 203-216.

/// Bláha I. A. 1931. Wspótczesna socjologia czeska, „Przegląd Socjologiczny", nr 2-4, s. 113-136.

/// Bláha I. A. 1948a. Socjologia inteligencji, „Przegląd Socjologiczny”, t. X, s. 97-138.

/// Bláha I. A. 1948b. Stan socjologii cæeskiej po wojnie, „Przegląd Socjologiczny", t. X, s. 634-637.

/// Bláha I. A. 1997. Ceskoslovenská sociologie: od svého vaniku do roku 1948, Doplněk. 
/// Bystroń J.S. 1917. Rozwój problemu socjologicznego w nauce polskiej, „Archiwum Komisji Badania Historii Filozofii w Polsce”, t. I, cz. I. [Datowane: 1915.]

/// Bystroń J.S. 1922. Rozvoj problému sociologického v polské védè, „Parlament”, r. I, s. 373-377, [na:] Nešpor Z.N., Kopecká A., red. 2011. Edice českých sociologických časopisu (CD-ROM), Sociologický ústav AV ČR - MathAn.

/// Chałubiński M. 1991. Polityka i socjologia. Studium koncepcji Juliana Hochfelda, Uniwersytet Warszawski. Wydział Filozofii i Socjologii.

/// Hochfeld J. 1956. O programu výzkumu pracovního prostredí na velkých stavbách socialismu, „Filosofický časopis”, nr 3, s. 441-448.

/// Kaltenberg-Kwiatkowska E. 2008. Jan Sedláček (1935-2008). Wspomnienie o naszym czeskim prryjacielu, „Studia Socjologiczne”, nr 4, s. 147151.

/// Kilias J. 1998. Naród a idea narodowa. Nacjonalizm T.G. Masaryka, Wydawnictwo Naukowe Scholar.

/// Kilias J. 2000. Narodowość jako problem naukowy. Naród w socjologii czeskiej okresu miedzywojennego, Wydawnictwo Naukowe Scholar.

/// Kilias J. 2001a. „Okno na świat”. O socjologii w Polsce i Czechostowacji przed rokiem 1968, „Myśl Socjaldemokratyczna”, nr 2, s. 99-105.

/// Kilias J. 2001b. „Socjologia bilansujaca” cæy „obiektywizm socjologicæny”? Dwa spory o charakter socjologii czeskiej okresu miedzywojennego, „Studia Socjologiczne", nr 2, s. 37-66.

/// Kilias J. 2012. Jak socjologowie opowiadali o socjologii. Dwa studia, Wydawnictwa Uniwersytetu Warszawskiego.

/// Klofáč J. 1956. K možnosti a potrebě sociologickébo výzkumu v ČSR, „Filosofický časopis”, nr 3, s. 449-452.

/// Kon I.S. i in. 1982. Déjiny buržoazni sociologie 19. a začatteu 20. století, Svoboda.

/// Komarov M.S. i in. 1983. Déjiny buř̌oazni sociologie proní poloviny 20. století, tłum. J. Sedláček, Svoboda. 
/// Konstantinov F.V. i in. 1981. Buržoazni sociologie a současnost, tłum. J. Šanderová, J. Večerník, Svoboda.

/// Krasnodębski Z. 2006. Zánik myšlenky pokroku, tłum. K. Tichá, Pavel Mervart.

/// Kraśko N. 1996. Instytucjonalizacja socjologii w Polsce 1920-1970, PWN.

/// Kraśko N. 2010. Instytucjonalizacja socjologii w Polsce 1970-2000, Wydawnictwa Uniwersytetu Warszawskiego.

/// Krzywicki L. 1948-1949. Dary jako jedna fáze vývoje výmèny výrobkè, cz. I-III, „Sociologická revue”, nr 1, 1-3 i 4, s. 13-21, 16-29 i 137-153.

/// Kubiczek F., red. 1992. Historia Polski w liczbach, z. 4: Oświata, nauka, kultura, GUS.

/// Kurczewska J. 1979. Naród w socjologii i ideologii polskiej. Analiza porównawcza wybranych koncepcji zprzetomu XIX $i$ XX wieku, PWN.

/// Labbé M. 2011. The Rockefeller Foundation Turns to the East: Polish Social Sciences Fellows during the Interwar Period. http://www.rockarch.org/publications/resrep/labbe.pdf; dostęp: 14.06.2015.

/// Machonin P. 1968. Struktura wspótczesnego spoleczeństwa czechostowackiego, „Studia Socjologiczno-Polityczne”, nr 25, s. 81-12.

/// Machonin P. i in. 1969. Ceskoslovenská společnost. Sociologická analýra sociálni stratifikace, Epocha.

/// Machotka O. 1938. Americká sociologie: sociálnípodminky væniku a rozvoje, Melantrich.

/// Macků J. 1968. Gtówne tendencje rozwojowe socjologii czechostowackiej, „Studia Socjologiczne", nr 3-4, s. 339-442.

/// Mikulka J. 1984. Slovanství a polské společnost v XIX. století, Academia.

/// Mirek F. 1930. Sociologie v Polsku (XIX. a XX. století), cz. I/II, „Sociologická revue", nr 1-2, s. 96-100, nr 3-4, s. 301-306.

/// Mirek F. 1934. O ideových proudech současné mládeže polské, „Sociologická revue", Nr 1-3, s. 80-89.

/// Morawski W. 2005. Ekonomická sociologie. Problémy, teorie, empirie, tłum. J. Ogrocký, Sociologické nakladatelství. 
/// Nešpor Z.R. 2011. Republika sociologů. Zlatá éra české sociologie v mequiválečném obdobi a kerátce po drubé svètové válce, Scriptorium.

/// Nešpor Z.R. i in. 2014. Dějiny české sociologie, Academia.

/// Nowak S. 1975. Metodologie sociologických výžkumi. Obecnéproblémy, tłum. J. Večerník, Svoboda.

/// Olechnicki K. 2003. Antropologia obrazu, Oficyna Naukowa.

/// Pecka E. 2011. Proces tzv. normalizace v české sociologï, „Historická sociologie - Historical Sociology", nr 1.

/// Petrusek M. 2004. Výnka sociologie v čase táni a v časech normalizace (1964-1989), „Sociologický časopis”, nr 5, s. 597-607.

/// Petrusek M. 2006. Společnost pozdni doby, Slon.

/// „Polish Sociological Review”. 2008. Nr 2 [numer złożony z tekstów czeskich autorów].

/// Richta R. i in. 1966. Civilizace na rozcesti: společenské a lidské souvislosti védeckotechnické revoluce, Svoboda.

/// Richta R. i in. 1971. Cywilizacja na rozdrożu: konsekwencje rewolucji naukowo-technicznej dla społeczeństwa $i$ dla człowieka, tłum. Andrzej Hodoly, Książka i Wiedza.

/// Sdèleni redakece. 1968. „Sociologický časopis” nr 4, s. 519-520 [tekst odredakcyjny].

/// Sedláček J. 1971. A.M. Rumjancev o kniže Jana Szczepańského, „Sociologický časopis”, nr 3, s. 316-318.

/// Sedláček J., Burianek J., Šubrt J. 2000. Mezigenerační rozprava o védě a životè, [w:] Jedinec a společnost. Sbornik ke 65. narozeninám doc. PhDr Jana Sedláčka, Katedra Sociologie FF UK, s. 13-31.

/// Skovajsa M. 2014. Rockefeller Foundation's Role in Promoting Social Sciences in Interwar Czechoslovakia, referat wygłoszony na XVIII ISA World Congress of Sociology, Yokohama.

/// Sowa J. 2011. Fantomowe ciało króla. Peryferyjne żmagania z. nowoczesna forma, Universitas.

/// Staniszkis J. 2006. Postkomunismus: ̨rod hádanky, tłum. P. Pšeja, CDK. 
/// Staniszkis J. 2009. O moci a bežmoci, tłum. J. Ogrocký, CDK.

/// „Statistická ročenka Republiky československé”. 1934.

/// „Statistická ročenka ČSSR”. 1963.

/// „Statistická ročenka Československé socialistické republiky”. 1988.

/// Sułek R. 2013. Zatrzymani w rozpedzie: o pierwszym pokoleniu studentón socjologii w Polsce, referat wygłoszony na XV Ogólnopolskim Zjeździe Socjologicznym w Szczecinie.

/// Szacki J. 1971. Utopie, tłum. J. Sedláček, Mladá fronta.

/// Szacki J. 1995. Wstęp: krótka historia socjologii polskiej [w:] Sto lat socjologii polskiej. Od Supińskiego do Szczepanskiego. Wybór tekstów, red. J. Szacki, PWN, s. 11-119.

/// Szczepański J. 1967. Sociológia: vývin problematiky a metód, Vydavatel’stvo politickej literatúry.

/// Szostkiewicz S. 1964. Sociologický výskum. Procedúry a techniky, tłum. J. Pašiak, Vydavatel'stvo politickej literatúry.

/// Szostkiewicz S. 1965. Sociologický výskum. Procedúry a techniky, tłum. J. Pašiak, Vydavatel'stvo politickej literatúry.

/// Szostkiewicz S. 1968. I spotkanie socjologón crechostowackich i polskich, „Studia Socjologiczne”, nr 1, s. 209-212.

/// Sztompka P. 2007. Vizuálni sociologie: fotografie jako vý̃̌kumná metoda, tłum. J. Ogrocký, Sociologické nakladatelství.

/// Št’astný V. i in., red. 1968. Slovanství v národním æ̌ivotě Cechio a Slovákù, Melantrich.

/// Štefánek B. 1948. Socjologia Stowacji, „Przegląd Socjologiczny”, t. X, s. 637-643.

/// Vaněk A. 1981a. Kapitoly z dějin buř̌oazní sociologie, FF UK - Státní pedagogické nakladatelství.

/// Vaněk A. 1981b. Úvod do dějin marxistického sociologického myšlení, FF UK - Státní pedagogické nakladatelství.

/// Voříšek M. 2012. The Reform Generation. 1960s Czechoslovak Sociology from a Comparative Perspective, Kalich. 
/// [Wiatr J.J.] 1967. Wiryta delegacji czechostowackiej w Instytucie Filozofii i Socjologii PAN, „Studia Socjologiczne”, nr 1, s. 303.

/// Wiatr J.J. 2008. Życie w ciekawych czasach, Europejska Wyższa Szkoła Prawa i Administracji.

/// Wincławski W. 1991. Lud, naród, socjologia. Studium o genęie socjologii stowackiej, Uniwersytet Mikołaja Kopernika.

Materiały archiwalne:

/// Rockefeller Archive Center: Fundacja Forda, rolka 2521, grant $57-$ 322: list Herberta Menzla do Stanleya T. Gordona z 10 października $1962 \mathrm{r}$.

/// Biuro PTS: Protokół z zebrania Zarządu Głównego PTS z dnia 9 grudnia $1966 \mathrm{r}$.

/// Biuro PTS: Protokół z zebrania Zarządu Głównego PTS z dnia 28 października $1969 \mathrm{r}$.

/// Biuro PTS: Protokół z zebrania Zarządu Głównego PTS z dnia 29 czerwca $1970 \mathrm{r}$.

/// Biuro PTS: Protokół z zebrania Zarządu Głównego PTS z dnia 16 grudnia $1971 \mathrm{r}$.

/// Biuro PTS: Protokół z zebrania Zarządu Głównego PTS z dnia 9 czerwca $1972 \mathrm{r}$.

Inne materiały:

/// Wywiad z Jerzym J. Wiatrem (1995).

/// Korespondencja i rozmowy z Janem Sedláčkiem (2003-2008).

\section{/// Abstrakt}

Artykuł dotyczy stosunków między czeskimi i polskimi środowiskami socjologicznymi. W obu krajach po I wojnie światowej socjologia uległa instytucjonalizacji, została zlikwidowana przez komunistów, by odrodzić 
się w okresie poststalinowskim. Prawdą jest, że w komunistycznej Czechosłowacji swobodnie rozwijała się tylko przez krótki okres w latach 60 . XX wieku. Mimo wzajemnego zainteresowania socjologów obu krajów ich wzajemne kontakty nie były szczególnie intensywne - za wyjątkiem lat 60 . Czesi zazwyczaj interesowali się bardziej polskimi naukami społecznymi niż polscy czeskimi. Intensywność i asymetrię ich wzajemnych relacji można wyjaśnić zmieniającą się pozycją obu krajów w nauce międzynarodowej. Po II wojnie światowej pozostały one na półperyferiach nauki zachodniej, chociaż w okresie komunizmu należały także do rzekomo alternatywnego kręgu wschodnioeuropejskiej socjologii marksistowskiej. Wyjątkowa rola polskiej socjologii w Czechosłowacji w latach 60. stanowiła więc wynik jej roli jako pośrednika w kontaktach z wiodącą socjologią zachodnią.

Słowa kluczowe:

socjologia polska, socjologia czeska, historia socjologii, międzynarodowe kontakty naukowe

\section{/// Abstract}

The paper deals with relations between Czech and Polish sociological communities. In both countries, sociology was institutionalised shortly after the First World War, liquidated by the Communists, and renewed in the post-Stalinist period, but in Communist Czechoslovakia, it developed relatively freely only during a brief period in the 1960s. There existed a mutual interest between the sociologists of the two countries, although they did not have much contact, except in the 1960s. Most of the time, the Czechs were more interested in Polish social science than the other way around. The intensity and asymmetry of their relations can be best explained by the changing position of both countries within the international scholarly community. After the Second World War, they remained on the semiperiphery of the Western scholarly community, even though in the Communist period they belonged to the supposedly alternative world of Marxist sociology. The exceptional position of Polish sociology in Czechoslovakia in the 1960s was therefore the result of its role as an intermediary for accessing the dominant Western sociology.

Key words:

Polish sociology, Czech sociology, history of sociology, international academic relations. 